Notes and Comments

\title{
Podisus sagitta (Fabricius) does not occur in Brazil: a corrigendum to Oliveira-Júnior et al. 2021
}

\author{
R. Brugnera ${ }^{a}$ (D) J. Grazia ${ }^{a}$ (D) and M. A. Soares ${ }^{b *}$ (D) \\ aUniversidade Federal do Rio Grande do Sul - UFRGS, Departamento de Zoologia, Programa de Pós-graduação em Biologia Animal, Laboratório \\ de Entomologia Sistemática, Porto Alegre, RS, Brasil \\ bUniversidade Federal dos Vales do Jequitinhonha e Mucuri - UFVJM, Laboratório de Controle Biológico de Insetos, Programa de Pós-graduação \\ em Produção Vegetal, Diamantina, MG, Brasil
}

Among the 65 genera of predatory stink bugs currently described, Podisus Herrich-Schäffer is one with the most taxonomic incongruences. The genus is the most speciose of the subfamily, with 35 species described, presenting a great morphological variety and several taxonomic arrangements throughout its history (Thomas, 1992; Brugnera et al., 2020; Roell et al., 2021). Some species are the target of studies regarding biological control, mainly Podisus maculiventris (Say, 1831) in North America, and P. nigrispinus (Dallas, 1851), P. sagitta (Fabricius, 1794), and P. fuscencens (Dallas, 1851) in Central and South America. The last three belong to the sagitta group, which can be recognized by the acute humeral angles, with a noticeable posterior projection (Thomas, 1992). Podisus nigrispinus is commonly found in all regions of Brazil and applied in different types of researches (Pires et al., 2015). Podisus fuscescens (identified as $P$. distinctus (Stål) in the last two decades) is also widely found in Brazil and is easily distinguished from P. nigrispinus by morphological characteristics of the pronotum and genitalia (Brugnera et al., 2020). Podisus sagitta is northern distributed and very similar to $P$. nigrispinus, being sympatric in Costa Rica, Panama, Colombia, and Venezuela (Thomas, 1992; Castro-Huertas et al. 2015).

Oliveira-Júnior et al. (2021) present a new record for Podisus sagitta (Fabricius, 1794) in Brazil, including information about its natural history based on specimens reared under laboratory conditions. The first determination of the species was made in 2016 by Dr. Jocélia Grazia as cited by Oliveira-Júnior et al. (2021). In 2016, Dr. Jocélia provided the identification based on Thomas's identification key and description (1992). More recently, with new studies and access to type specimens of Podisus, the diagnostic delimitations of this species have been clarified, providing a more precise identification (Brugnera et al., 2020). During the review process of the manuscript of OliveiraJúnior et al. (2021), the identification made in 2016 was corrected to Podisus nigrispinus (Dallas, 1851); however, it was published incorrectly as $P$. sagitta. This note aims to correct that misidentification.
This is not the first time that Podisus nigrispinus and Podisus sagitta are confounded. Clercq and Degheele (1995) also reported the same misidentification of specimens collected in Surinam (Clercq and Degheele, 1990). Podisus nigrispinus and $P$. sagitta are very similar in overall morphology, including the parameres of male genitalia. They can be distinguished mainly by the shape and coloration of the pronotum. The anterolateral margins of the pronotum present a distinct coloration and are concave in P. nigrispinus, which varies from pale to red, always differing from the pronotal disc (Figures 1d, 1f). P. sagitta does not present this feature, being the anterolateral margins of pronotum sinuous and concolorous with the disc (Figures 1a and 1c). Additionally, P. sagitta usually presents the humeral angles anteriorly directed (Figure 1c), instead of laterally directed as observed in P. nigrispinus (Figure 1f). In addition, females of $P$. sagitta present a single dark spot in the VII sternite (Figure 1b), instead of a series of spots from III to IV sternites usually observed in females of P. nigrispinus (Figure 1e).

The known species distribution (country records) is: Podisus sagitta - United States (Texas, Florida, and New Mexico), Mexico, Guatemala, El Salvador, Honduras, Nicaragua, Costa Rica, Panama, Cuba, Bahamas, Jamaica, Dominican Republic, Haiti, Puerto Rico, Saint Vincent and the Grenadines, Curaçao, Trinidad and Tobago, Colombia, and Venezuela (Thomas, 1992; Castro-Huertas et al., 2015; GBIF, 2021) (Figure 2). Podisus nigrispinus - Costa Rica, Panama, Colombia, Venezuela, Ecuador, Surinam, Guyana, French Guiana, Brazil, Peru, Bolivia, Argentina, Paraguay, and Uruguay (Thomas, 1992; Dellapé et al. 2003; Lupoli, 2019; GBIF, 2021) (Figure 2).

In summary, the results presented by OliveiraJúnior et al. (2021) must be assigned to P. nigrispinus and not to P. sagitta. We warn that the classification of Podisus is currently unresolved, including the genus monophyly, the diagnosis of species and the available identifications keys. Thus, the identification of the species needs to be done with caution to avoid future misinterpretations.

*email: marcusasoares@yahoo.com.br

Received: August 26, 2021 - Accepted: November 18, 2021 


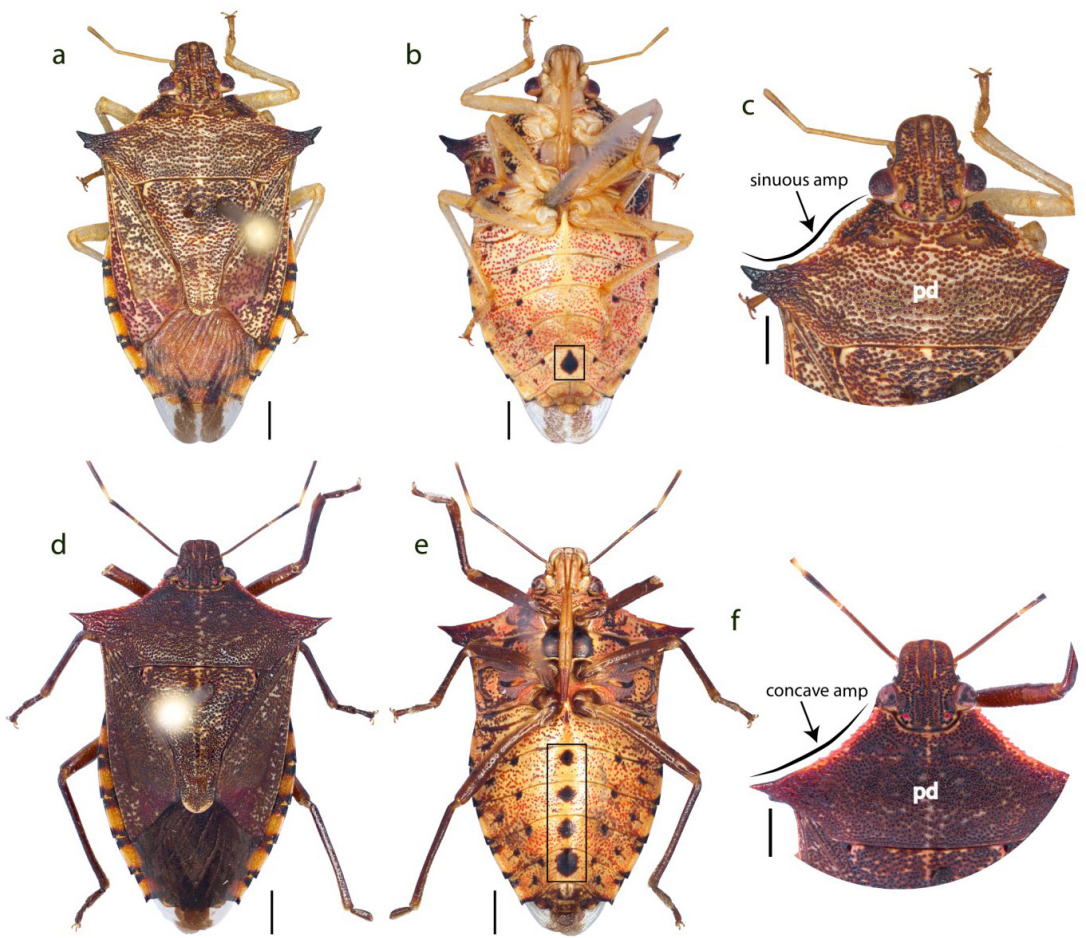

Figure 1. Habit of Podisus sagitta (a-c) and Podisus nigrispinus (d-e). (a) and (d) dorsal view; (b) and (e) ventral view; (c) and (f) head and pronotum in dorsal view. amp = anterolateral margin of pronotum; $\mathrm{pd}=$ pronotal disc. Squares in the figures b and e represent the distribution of dark spots in the female sternites.

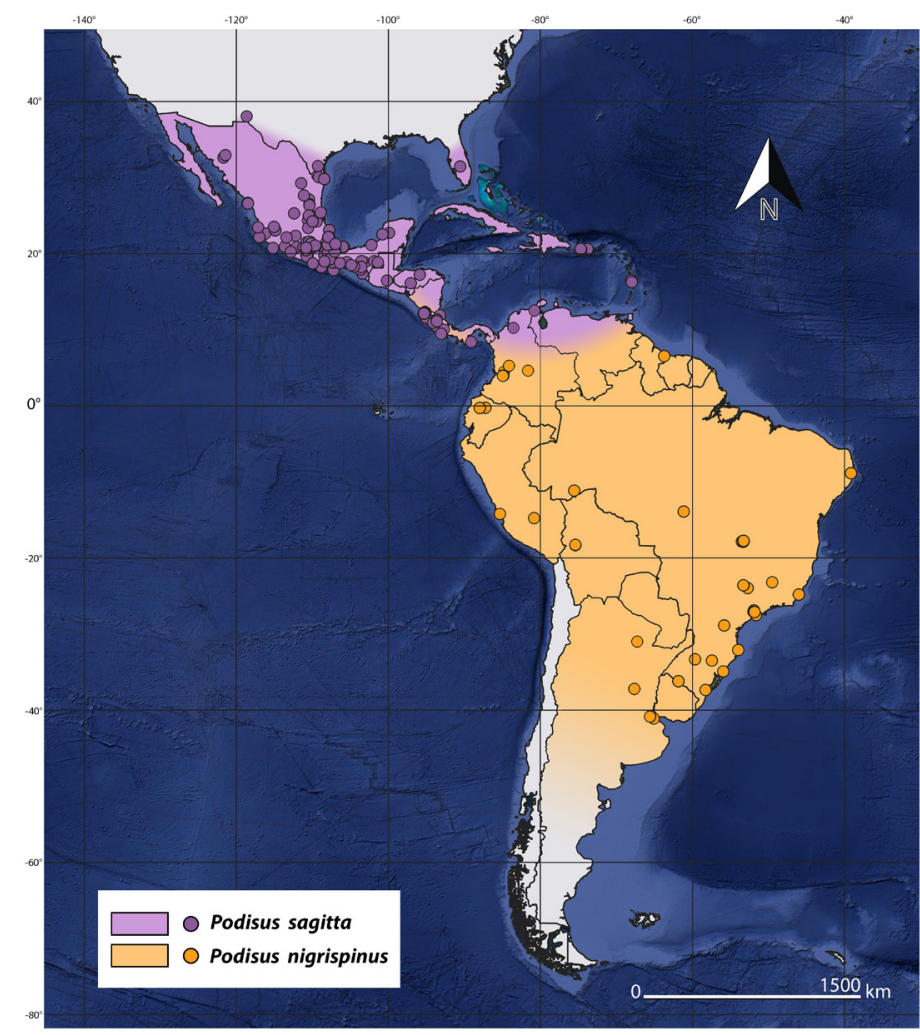

Figure 2. General distribution of Podisus sagitta (Fabricius) and Podisus nigrispinus (Dallas) in the American continent. Spots represent GBIF occurrences (GBIF, 2021). 


\section{References}

BRUGNERA, R., ROELL, T., CAMPOS, L.A. and GRAZIA, J., 2020 Taxonomy of widespread Neotropical species of Podisus HerrichSchäffer (Hemiptera: Pentatomidae: Asopinae): redescription of P. distinctus (Stål, 1860) and revalidation of P. fuscescens (Dallas, 1851).Zootaxa, vol. 4751, no. 3, zootaxa.4751.3.7. http://dx.doi. org/10.11646/zootaxa.4751.3.7. PMid:32230409.

CASTRO-HUERTAS, V., SCHWERTNER, F.C. and FERNÁNDEZ, F., 2015. New records of stink bugs (Hemiptera: Pentatomidae) from Colombia. Zootaxa, vol. 3973, no. 3, pp. 553-566. http://dx.doi. org/10.11646/zootaxa.3973.3.9. PMid:26249877.

CLERCQ P. and DEGHEELE, D., 1990. Description and life history of the predatory bug Podisus sagitta (Fab.) (Hemiptera: pentatomidae). Canadian Entomologist, vol. 122, no. 6, pp. 1149-1156. http://dx.doi.org/10.4039/Ent1221149-11.

CLERCQ, P. and DEGHEELE, D., 1995. Podisus nigrispinus (Dallas) and Podisus sagitta (Fabricius) (Heteroptera: Pentatomidae): correction of a misidentification. Canadian Entomologist, vol. 127, no. 2, pp. 265-266. http://dx.doi.org/10.4039/Ent127265-2.

DELLAPÉ, P.M., MARTíNEZ, A.P. and COSCARÓN, M.C., 2003. New distributional records for the asopine pentatomids in temperate South America. Zootaxa, vol. 318, no. 1, pp. 1-16. http://dx.doi. org/10.11646/zootaxa.318.1.1.

GLOBAL BIODIVERSITY INFORMATION FACILITY - GBIF, 2021. GBIF Occurrence Download. Scientific name: Podisus sagitta
(Fabricius, 1794). Podisus nigrispinus (Dallas, 1851). https:// doi.org/10.15468/dl.bwze8m.

LUPOLI, R., 2019. First catalogue of the Asopinae (Hemiptera, Pentatomidae) from French Guiana. Zootaxa, vol. 4668, no. 1, pp. 76-88. http://dx.doi.org/10.11646/zootaxa.4668.1.4. PMid:31716639.

OLIVEIRA-JÚNIOR, G.G.S., OLIVEIRA, D.K.S., VIEIRA, E.R.D., SOUZA, M.W.R., SANTOS, M.M., ASSIS-JÚNIOR, S.L. and SOARES, M.A., 2021. First record of the predatory stink bug Podisus sagitta (Hemiptera: Asopinae) in Brazil. Brazilian Journal of Biology = Revista Brasileira de Biologia, vol. 82, e236863. http://dx.doi. org/10.1590/1519-6984.236863. PMid:34133552.

PIRES, E.M., SOARES, M.A., NOGUEIRA, R.M., ZANUNCIO, J.C., MOREIRA, P.S.A. and OLIVEIRA, M.A., 2015. Seven decades of studies with Asopinae predators in Brazil (1933•-○2014). Bioscience Journal, vol. 31, no. 5, pp. 1530-1549. http://dx.doi. org/10.14393/BJ-v31n5a2015-27335.

ROELL, T., BRUGNERA, R. and LEMAÎTRE, V.A., 2021. Lost and found: discovery of the presumed lost type of Arma pallipes Dallas, new synonymy and description of two new species of Podisus Herrich-Schäffer (Hemiptera: Pentatomidae: Asopinae).Zootaxa, vol. 4958, no. 1, zootaxa.4958.1.33. http://dx.doi.org/10.11646/ zootaxa.4958.1.33. PMid:33903480.

THOMAS, D.B., 1992. Taxonomics synopsis of the Asopinae Pentatomidae (Heteroptera) of the Western Hemisfere. Lanham: Entomological Society of America, 147 p. Thomas Say Foundation Monographs. 